\title{
Economic valuation of net social benefit of seasonal fishing ban in selected maritime states of India
}

\author{
R. NARAYANAKUMAR, J. JAYASANKAR, SHYAM S. SALIM, U. GANGA \\ AND E. VIVEKANANDAN \\ ICAR-Central Marine Fisheries Research Institute, Kochi - 682 018, Kerala, India \\ e-mail: ramani65@gmail.com
}

\begin{abstract}
Seasonal fishing ban (SFB) is followed along the Indian coast for the past 15 to 25 years for sustaining marine fishery resources. However, the effect of the SFB on fishery resources and societies has not yet been established. In this paper, an attempt has been made to evaluate the net social benefit of the SFB which will help to throw light on the impact of SFB and guide to substantiate or recommend alternate/improved management measures to sustain marine fisheries. In the present study, the economic valuation of SFB was carried out in five selected maritime states of the country. It was found that the incremental biomass ranged from 5 to $9 \%$. The net social benefit was also positive in all the states, which ranged from ₹1,097 lakhs in Andhra Pradesh to ₹2,796 lakhs in Tamil Nadu. Based on performance of SFB in terms of net societal benefits, the states were ranked in the order, Tamil Nadu, Kerala, Gujarat, Karnataka followed by Andhra Pradesh. Results of the study recommends continuation of SFB, however, it should not be considered as a stand-alone practice and should be considered only as part of a bundle of management measures for sustaining marine fisheries in India.
\end{abstract}

Keywords: Economic valuation, Incremental biomass, Seasonal fishing ban, Social benefit, Sustainability, Transaction cost

\section{Introduction}

Fishery resources are renewable natural resources but exhaustible if harvested indiscriminately. There are examples wherein certain resources have become extinct (or) collapsed due to unsustainable harvest (Schwartzlose et al., 1999). Marine fisheries of tropics are influenced by variegated intrinsic factors arising out of multispecies, multigear and multisector players and extraneous factors like vagaries of monsoon and locally prevalent socio-economic conditions thereby making it unadaptable or non-adaptable of any existing template elsewhere and hence their management has to be cast in the closest possible locally devised framework suiting to the region. Besides, in "multispecies and multi-gear fishery such as in India, compounded by biological and technological interventions, the application of classical assessment procedures may be untenable and irrelevant for obvious reasons and hence fishery managers require some indicators of status of the fishery relevant to chosen reference point" (Srinath et al., 2006).

The management of fisheries in India is governed by rules and regulations formulated under the Indian Fisheries Act 1897. Among the many tools available for fisheries management, seasonal fishing ban (SFB) is the only instrument which is being diligently followed in all maritime states of India by implementing closed season of 45 to 75 days for mechanised and motorised fishing vessels as a corollary to their Marine Fishing Regulation Acts (Table 1).

It is seen from the table that the ban duration, season and crafts exempted from fishing ban varied across the maritime states. Kerala was the first state to introduce fishing ban in 1988, followed by Goa, Karnataka and Maharashtra. After the intervention of the Ministry of Agriculture, Government of India since 1998, the SFB has been made uniform all along the west-coast (June 15 - July 31 ) and east- coast (April 15 - May 31) states and Union Territories. From 2015, the ban period has been extended to 60 days in both the coasts i.e., from April 15 to June 14 in the east-coast and from 1 June to 31 July in west-coast. Gujarat, Goa and Maharashtra follow total ban during the period. All the other sates allow motorised and traditional craft with limitations on engine horse power.

SFB was introduced with the purpose of protecting the spawners during peak spawning season, reducing the fishing effort, giving respite to the sea floor and safety of fishermen at sea. Since the inception of this ban, the marine fisheries sector has undergone immense technological, economic and social changes besides, generating controversies. However, even after several years of implementation of SFB, there are no specific 
Table 1. Enforcement of SFB in Maritime states of India

\begin{tabular}{|c|c|c|c|c|c|}
\hline State & $\begin{array}{l}\text { Year of } \\
\text { introduction }\end{array}$ & $\begin{array}{l}\text { Period of } \\
\text { notification* }\end{array}$ & $\begin{array}{l}\text { Number of } \\
\text { days }\end{array}$ & $\begin{array}{l}\text { Type of fishing } \\
\text { banned }\end{array}$ & $\begin{array}{l}\text { Type of fishing } \\
\text { permitted }\end{array}$ \\
\hline Gujarat & 1998-99 & 10 June - 15 August & 67 & All crafts & NIL \\
\hline Karnataka & 1989 & 15 June -10 August & 57 & $\begin{array}{l}\text { All crafts except } \\
\text { motorised OBM/IBM } \\
\text { vessels up to } 25 \mathrm{hp} \text { engine }\end{array}$ & $\begin{array}{l}\text { Motorised up to } \\
25 \text { hp engine }\end{array}$ \\
\hline Kerala & 1988 & 15 June - 31 July & 47 & $\begin{array}{l}\text { Mechanised } \\
\text { vessels/motorised } \\
\text { crafts }>10 \text { hp engine }\end{array}$ & $\begin{array}{l}\text { All traditional /motorised } \\
\text { crafts up to } 10 \mathrm{hp} \text { engine }\end{array}$ \\
\hline Tamil Nadu & 2001 & 15 April - May 31 & 47 & $\begin{array}{l}\text { Mechanised } \\
\text { fishing/trawlers }\end{array}$ & $\begin{array}{l}\text { All non-motorised and } \\
\text { motorised crafts with less } \\
\text { than } 25 \mathrm{hp} \text { engine }\end{array}$ \\
\hline Andhra Pradesh & 2000 & 15 April - May 31 & 47 & $\begin{array}{l}\text { Trawlers and } \\
\text { motorised crafts } \\
>25 \text { hp engine }\end{array}$ & $\begin{array}{l}\text { Traditional/ motorised } \\
\text { crafts with }<25 \text { hp engine }\end{array}$ \\
\hline
\end{tabular}

Source: Policy brief seasonal fishing ban, CMFRI Spl. Publn. No.103, 2010

answers to the following questions: Has the natural capital asset and its value increased? Has the ban improved marine ecosystem services? What is the management cost vis-a-vis benefits? How does each maritime state perform? Answers to these questions are needed to arrive at effective management decisions to sustain this sector. With this background, an attempt has been made in this paper to evaluate the net social benefit of the SFB which will help to throw light on the impact of SFB and guide to substantiate or recommend alternate/improved management measures to sustain marine fisheries in India.

\section{Materials and methods}

The coastal ecosystem provides a variety of services. Among them, fishery is an important provisioning service with supplements from supporting and cultural services. Implementation of the SFB is likely to provide the following benefits to the ecosystem, like sustainable catch which provides assured income to the fishers; reduced fuel use and $\mathrm{CO}_{2}$ emission (due to reduction in mechanized fishing effort for 45 to 60 days, thus reducing the use of fuel and carbon emissions) as well as reduced impact on biodiversity of our seas. In this paper the valuation of net social benefit due to the implementation of the SFB has been attempted. The net social benefit was worked out estimating the incremental economic benefit derived due to SFB and transaction cost of implementation of SFB and deducting the transaction cost from the incremental economic benefits.

\section{Selection of study area}

Five maritime states viz., Tamil Nadu, Andhra Pradesh, Kerala, Karnataka and Gujarat were selected for the study considering their importance in marine fisheries in India in terms of coastal length; share in country's total landings, number of marine fishing villages and landing centres and dependency on fisheries (Table 2, Fig. 1).

Among the maritime states, Gujarat has the longest coast line with the maximum number of mechanised crafts. Kerala accounted for about $25 \%$ the total fish landings of the country followed by Gujarat and Tamil Nadu during 2011-13. However, in 2014, Gujarat (19.8\%) stood first followed by Tamil Nadu (18.5\%) and Kerala (16\%) (CMFRI, 2014; 2015).

The response of fishing communities to SFB is different among the states depending on their literacy, awareness and social status as known from our previous studies. Among the selected states, the literacy rate, awareness and social status of the fisherfolk in Kerala are better than in other states. Hence, expectations and societal

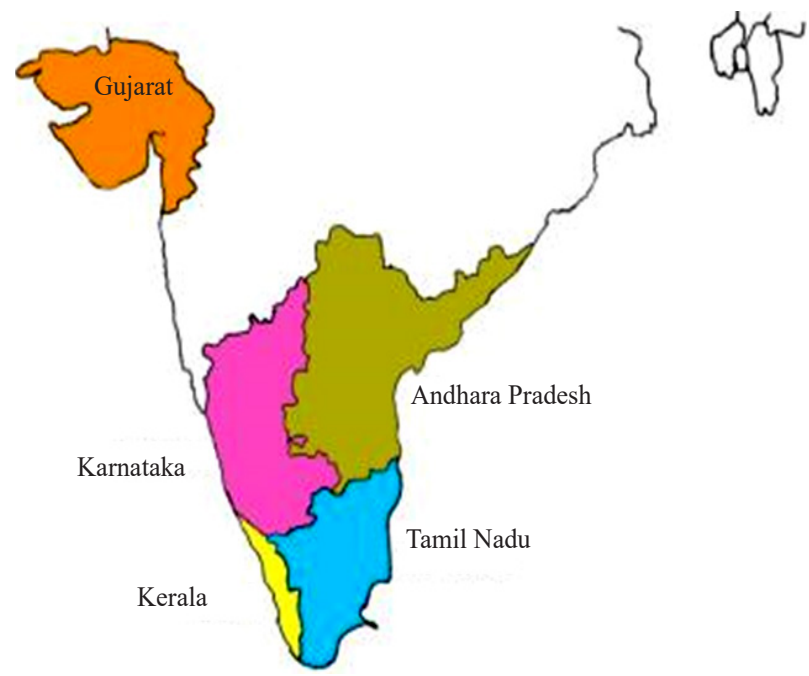

Fig. 1. Map showing the maritime states selected for the study 
Table 2. Marine fishery profile of the selected maritime states

\begin{tabular}{|c|c|c|c|c|c|c|c|c|c|}
\hline \multirow[t]{2}{*}{ State } & \multirow{2}{*}{$\begin{array}{l}\text { Coast } \\
\text { line } \\
(\mathrm{km})\end{array}$} & \multirow{2}{*}{$\begin{array}{l}\text { Average } \\
\text { annual } \\
\text { landngs } \\
2011-2013 \\
\text { (t) }\end{array}$} & \multirow[b]{2}{*}{$\begin{array}{l}\text { Share of } \\
\text { major } \\
\text { resources } \\
(\% \text { total } \\
\text { fish } \\
\text { landings })\end{array}$} & \multirow{2}{*}{$\begin{array}{l}\text { No. of } \\
\text { marine } \\
\text { fishing } \\
\text { villages }\end{array}$} & \multirow{2}{*}{$\begin{array}{l}\text { No. of } \\
\text { marine } \\
\text { fish } \\
\text { landing } \\
\text { centres }\end{array}$} & \multicolumn{3}{|c|}{ No. } & \multirow{2}{*}{$\begin{array}{l}\text { Fisherfolk } \\
\text { population } \\
\text { (in lakhs) }\end{array}$} \\
\hline & & & & & & Mechanised\# & Motorised\# & Non-mechanised\# & \\
\hline Andhra Pradesh & 974 & $\begin{array}{l}2,81,688 \\
(10 \%)\end{array}$ & $\begin{array}{l}\text { PL-56 } \\
\text { DM-29 } \\
\text { CR-13 }\end{array}$ & 555 & 353 & 3,167 & 10,737 & 17,837 & 6.05 \\
\hline Tamil Nadu & 1,076 & $\begin{array}{l}6,54,569 \\
(19 \%)\end{array}$ & $\begin{array}{l}\text { PL-61 } \\
\text { DM-29 } \\
\text { CR-6 } \\
\text { ML-4 }\end{array}$ & 573 & 407 & 10,692 & 24,942 & 10,436 & 8.02 \\
\hline Kerala & 590 & $\begin{array}{l}7,51,223 \\
(25 \%)\end{array}$ & $\begin{array}{l}\text { PL-73 } \\
\text { DM-14 } \\
\text { CR-6 } \\
\text { ML-7 }\end{array}$ & 222 & 187 & 4,722 & 11,175 & 5,884 & 6.10 \\
\hline Karnataka & 300 & $\begin{array}{l}4,34,063 \\
(12 \%)\end{array}$ & $\begin{array}{l}\text { PL-64 } \\
\text { DM-24 } \\
\text { CR-5 } \\
\text { ML-7 }\end{array}$ & 144 & 96 & 3,643 & 7,518 & 2,862 & 1.67 \\
\hline Gujarat & 1,600 & $\begin{array}{l}7,20,591 \\
(20 \%)\end{array}$ & $\begin{array}{l}\text { PL-36 } \\
\text { DM-35 } \\
\text { CR-21 } \\
\text { ML-8 }\end{array}$ & 247 & 121 & 18,278 & 8,238 & 1,884 & 3.96 \\
\hline
\end{tabular}

Figures in brackets indicate the average share of the states in India's marine fish landings

$P L$ - Pelagic resources; DM - Demersal resources; $C R$ - Crustacean resources; $M L$ - Molluscan resources

*National marine fisheries census 2010 (CMFRI, 2012)

\#Mechanised sector: Use engine power for cruise and fishing: Motorised sector: Use engine power for cruise and fishing done manually; Non-mechanised sector: Generally use manual labour for cruise and fishing

response to fishing ban are higher in Kerala. However, Kerala being highly fisheries-centric, poses many challenges for fisheries administrators. Andhra Pradesh and Tamil Nadu are implementing the ban since 2001 for 45 days from April 15 to May 31 and in general, there was an acceptance for the ban in light of the rejuvenation of the fish stocks though there were some reservations regarding the season of enforcement. In Gujarat, the literacy level of the fishers was $44 \%$ (excluding children below five years). The SFB is in force from 1998-99 onwards. It was found that historically, the fishers here were enforcing voluntary ban even earlier. In Karnataka, the fishers had a literacy level of $64 \%$ (excluding children below five years). The SFB is in force in the state since 1989. There is a marginal difference in the ban period between the two major fishing districts namely Dakshina Kannada and Uttara Kannada.

\section{Data}

The secondary data on marine fish landings was collected from the National Marine Fish Landing Data Centre (NMFLDC) of the ICAR-Central Marine Fisheries Research Institute (ICAR-CMFRI) for the analysis. Time series data for a period of 40 years on resources landed along with the corresponding fishing effort [both in units and in hours (actual fishing hours)] were collected (Table 3).

The primary data on transaction cost was collected from the Department of Fisheries of the respective states using a pre-tested schedule. The data on information costs of notification of SFB and enforcement cost of SFB were worked out based on the time spent by the officials involved in the enforcement process and their monthly salaries. The data on compensation paid to fishers during the ban period was also collected, but this does not form a part of the transaction cost.

Analytical tools

Estimation of incremental benefit: Quantification of incremental fish biomass due to SFB

The economic benefit of SFB was assessed following Vivekanandan et al. (2010) by considering the percentage growth increment of fish during SFB. Logically, the biomass of resources would increase during the ban period as otherwise it would have been exploited as small sized juveniles by the fishery. In order to estimate the weight 
Table 3. Details of data collected from National Marine Fisheries Data Centre of ICAR-CMFRI for analysis indicating the period for which the data were available

\begin{tabular}{lllllll}
\hline State & Annual landings & Annual effort & Quarterly landings & Quarterly effort & Monthly landings & Monthly effort \\
\hline Gujarat (zw-sw) & $1970-2013$ & $1985-2013$ & $1985-2013$ & $1985-2013$ & $2002-2013$ & $2007-2013$ \\
Karnataka (zw-sw) & $1970-2013$ & $1985-2013$ & $1985-2013$ & $1985-2013$ & $2002-2013$ & $2007-2013$ \\
Kerala (zW-sw) & $1970-2013$ & $1985-2013$ & $1985-2013$ & $1985-2013$ & $2002-2013$ & $2007-2013$ \\
Tamil Nadu (zw-sw) & $1970-2013$ & $1985-2013$ & $1985-2013$ & $1985-2013$ & $2002-2013$ & $2007-2013$ \\
Andhra Pradesh (zw-sw) & $1970-2013$ & $1985-2013$ & $1985-2013$ & $1985-2013$ & $2002-2013$ & $2007-2013$ \\
\hline
\end{tabular}

zw: Zone-wise; sw- Species-wise

increment of important resources during ban period, the growth parameters, $\mathrm{k}$ (growth curvature), $\mathrm{W}_{\mathrm{t}}$ (weight of fish at age $\mathrm{t}$ ) and $\mathrm{W}_{\infty}$ (weight at maximum length) as well as the length-weight relationship of the major species representing the resources exploited by the mechanised gears were collected from a number of published sources. The von Bertalanffy growth function (VBGF) used was:

$$
\mathrm{Wti}=\mathrm{W}_{\infty \mathrm{i}}\left(1-\exp { }^{(-\mathrm{kti})}\right)^{3}
$$

where, $\mathrm{W}_{\mathrm{ti}}=$ weight of fish at age $\mathrm{t}$ for the $\mathrm{i}^{\text {th }}$ resource, $\mathrm{k}=$ annual growth coefficient and $\mathrm{W}_{\infty \mathrm{i}}=$ weight at $\mathrm{L}_{\infty}$ for the $\mathrm{i}^{\text {th }}$ resource

The incremental percentage biomass estimates were adopted from Vivekanandan et al. (2010), which were then applied to arrive at the total increment in the biomass of the major fishery resources based on the catch data recorded in the month prior to start of the SFB, as applicable to the various maritime states studied.

\section{Economic valuation of the incremental growth}

The economic benefit of SFB was assessed from the incremental growth that was attained during the fishing ban. The incremental weight $(t)$ of each species was multiplied by the price per $\mathrm{t}$ (geometric mean of the last three years at the landing centre price level and retail price level as available with the Socio-economic Evaluation and Technology Transfer Division of ICAR-CMFRI) of the respective species to arrive at the total estimate as follows:

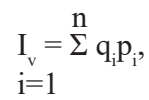

where, $I_{v}=$ incremental value during the ban period, $\mathrm{q}_{\mathrm{i}}=$ incremental growth (biomass) of species, $\mathrm{p}_{\mathrm{i}}=$ price per $\mathrm{kg}$ of the species and $i=$ species

\section{Transaction cost of implementation of Seasonal Fishing Ban}

"Transaction cost is the cost incurred to carryout transaction in a market which involves discovery of the person whom one has to deal with, to perform negotiations to arrive at a decision, to make contract and further monitoring of the terms of contract" (Ronald Coase, 1937). The concept of transaction cost has been defined by various economists at different points of time as the expenses of organising and participating in a market or implementing a government policy (Gordon, 1994); as the cost of exchange (Barzel, 1985) and as the cost of exchanging ownership titles (Demsetz, 1968). In simple terms, transaction cost refers to the costs involved in implementation and enforcement of management measures or acts or legislation. This includes the expenditure incurred by the Government in implementing any regulation.

Transaction cost primarily involves: (i) Search and information costs which covers cost of educating the stakeholders, getting information and related costs; (ii) Bargaining and decision costs that includes cost of arriving at a particular decision or programme for implementation of fishing ban as well as (iii) Policing and enforcement costs comprising, cost of enforcing a particular decision or program for e.g. cost of enforcing SFB.

In this study, the transaction cost was divided into major heads namely information cost, enforcement cost and compensation cost. Information cost relates to the expenses incurred in the information exchange on the ban to the masses either through audio or visual media like radio, newspaper, television, print notices and others including awareness campaigns.

The enforcement costs included the expenses computed for enforcing the ban across the coast by way of involving officials in the enforcement from the department of fisheries, police force and the coast guard patrol. Also cost is computed for the hiring charges of the patrol boat and its petrol and oil (POL) expenses. The sum of information cost and enforcement cost was taken as the transaction cost as there were no bargaining costs involved in this process.

In states where there were no direct enforcement officials, the cost of transaction was estimated by working out the portion of the time spent by the officials in enforcement functions. In states like Gujarat, where the 
coast guards are entrusted with the enforcement of SFB, the proportion of time spent on monitoring of SFB was ascertained and the corresponding share of their salaries was accounted in the enforcement cost.

The compensation cost included incentives and compensation paid during the ban such as free rations and cash allowance paid to the fishers in lump sum or with sharing from the Central and State government during the ban period. But it is to be noted that compensation cost was not part of transaction cost.

\section{Estimation of net social benefit}

The net social benefit was worked out by deducting the transaction cost from the incremental benefit accrued due to the implementation:

Net social benefit $(₹)=[$ Incremental benefit due to SFB (₹) - Transaction cost (₹)]

\section{Results and discussion}

\section{Incremental growth and benefit}

The growth in biomass due to increase in body size of fishes during the ban period was computed using the VBGF, following Vivekanandan (2010) and cumulated for all resources and the incremental growth was computed. The incremental benefit thus estimated was higher in west coast states of Kerala, Karnataka and Gujarat (9\%) compared to Andhra Pradesh (5\%) and Tamil Nadu (8\%) (Table 4).

\section{Transaction costs}

Kerala

The estimated transaction cost in the implementation of SFB in Kerala (Table 5) shows that, the total transaction cost in 2014 was ₹248.14 lakhs out of which the information costs accounted for a major share $84.63 \%$ (₹210 lakhs) followed by the enforcement cost, $15.37 \%$ (₹38.14 lakhs) The awareness about SFB was created through various channels of communication like personal, electronic, print media and also through small publications. The expenses incurred to advertise in media, publication of notices and awareness campaigns were computed as information costs.

Besides the transaction cost, the government also gives compensation to the fishermen during the fishing ban period. It includes cash allowance and free rations. The total compensation cost was ₹5,802.38 lakhs out of which the free ration shared ₹1,392.38 lakhs (24\%) followed by cash allowance, ₹4,410 lakh (74\%) (Table 6).

\section{Andhra Pradesh}

From Table 7. it is seen that the total transaction cost in Andhra Pradesh worked out to ₹172.52 lakhs out of which the enforcement costs accounted for a major share of $97.71 \%$ (₹168.58 lakhs) followed by the information cost $2.29 \%$ ( $₹ 3.95$ lakhs). Awareness about SFB is created through various channels of communication like personal, electronic and print media.

Table 4. Incremental economic benefit due to SFB

\begin{tabular}{|c|c|c|c|c|c|}
\hline Parameters & Kerala & Karnataka & Gujarat & Andhra Pradesh & Tamil Nadu \\
\hline Catch ( $(\mathrm{t})$ in 45 - 60 days (if there is no fishing ban) & 49,344 & 35,900 & 35,523 & 22,265 & 67,015 \\
\hline Catch (t) in 45-60 days (if there is fishing ban) & 53,785 & 39,131 & 38,720 & 24,046 & 72,377 \\
\hline Increment in catch during ban period $(\mathrm{t})$ & 4,441 & 3,231 & 3,197 & 1,781 & 5,361 \\
\hline Increment rate $(\%)$ & 9 & 9 & 9 & 8 & 8 \\
\hline Value of incremental catch estimated at landing centre price (₹ lakhs) $)^{*}$ & 2,729 & 1,701 & 2,129 & 1,266 & 2,809 \\
\hline Value of incremental catch estimated at retail market price (₹ lakhs) & 4,053 & 3,781 & 2,897 & 1,980 & 4,620 \\
\hline
\end{tabular}

The incremental growth due to SFB and the corresponding monetary value of the incremental growth was estimated. The value of the incremental catch captures the average price the fish had realised at the landing centre as well as retail market levels due to increase in body size for 45-60 days. The estimated value of the incremental biomass ranged from ₹1,266 lakhs in Andhra Pradesh to ₹2,809 lakhs in Tamil Nadu at landing centre price level (point of first sales). At the retail market level (point of last sales), the estimated value ranged from ₹1,980 lakhs in Andhra Pradesh to ₹4,620 lakhs in Tamil Nadu (average for the last three years) during 2013.

\section{Tamil Nadu}

In Tamil Nadu, the ban is implemented for a period of 45 days from $15^{\text {th }}$ April to $29^{\text {th }}$ May of every year along the entire east-coast of the state starting from Thiruvallur Revenue District to Kanyakumari Town in Kanyakumari District and from $15^{\text {th }}$ June to $29^{\text {th }}$ July of every year along the west-coast portion of the state in the Kanyakumari District from Kanyakumari to Neerodi Village limit. The government of Tamil Nadu do not make any public announcements through media regarding the enforcement of seasonal fishing ban. The announcements on ban are made through media. However, instructions are given to 
Table 5. Estimation of transaction cost in Kerala, 2014

\begin{tabular}{llll}
\hline No. & Components of transaction cost & Amount (₹ lakhs) & \% share to total \\
\hline A & Information cost & 210.00 & 84.63 \\
B & Enforcement cost & & \\
& Salary of government staff & 13.63 & 5.49 \\
& Patrolling & 21.71 & 8.75 \\
& Fuel & 2.80 & 1.13 \\
& Total enforcement cost & 38.14 & 15.37 \\
C & Total transaction cost & 248.14 & 100.00 \\
\hline
\end{tabular}

Table 6. Compensation allowances paid to fishers during SFB, Kerala

\begin{tabular}{lll}
\hline $\begin{array}{l}\text { Components of } \\
\text { compensation cost }\end{array}$ & $\begin{array}{l}\text { Amount } \\
(₹ \text { lakhs })\end{array}$ & $\begin{array}{l}\text { Percent to total } \\
\text { compensation cost }\end{array}$ \\
\hline Free ration & $1,392.38$ & 24.00 \\
Cash allowance & $4,410.00$ & 76.00 \\
Total compensation cost & $5,802.38$ & 100.00 \\
\hline
\end{tabular}

families (2014) amounted to ₹30,01,59,565 which included the allowance of ₹2,000 per family.

\section{Karnataka}

In Karnataka, announcements regarding the ban are made through newspapers as news item. Hence no cost is involved. No officials are specifically engaged for enforcement of closed fishing season. The staff members

Table 7. Estimation of transaction cost in Andhra Pradesh

\begin{tabular}{llll}
\hline No. & Components of transaction cost & Amount (₹ lakhs) & \% share to total \\
\hline A & Information cost & $3.95^{*}$ & 2.29 \\
B & Enforcement cost & 141.88 & \\
i & Salary - Department of Fisheries & 26.71 & \\
ii & Salary - Police officials & 168.58 & 97.71 \\
iii & Total enforcement cost & & \\
\hline
\end{tabular}

"This cost was incurred by the Reliance Foundation on their own. Reliance India Ltd. initiated a programme to connect farmers and fishermen as a part of their expansion programme. Since this exercise aimed at creating awareness about SFB, the cost incurred by them was taken as information cost (as a proxy to the expenses incurred by the Government of AP).

authorised officers through Office Memorandum. Further, notice is issued through newspapers as Press Release and no cost is involved.

The enforcement is done with the help of Department of Fisheries officials which includes Joint Director, Deputy Director, Assistant Director, Fisheries inspectors, Fisheries officers and Sea guards. Patrolling is carried out in Kanyakumari District using fishing boats of local fishermen with 2 patrolling trips with 2 boats per week for 6 weeks during east coast ban period (i.e. $4 \times 6=24$ boat trips) and 2 patrolling trips with 2 boats per week for 6 weeks during west coast ban period. (i.e. $4 \times 6=24$ boat trips). There are no hiring charges for patrolling boat; however 2001 of diesel per boat per trip is provided for all the 48 trips which require a total diesel requirement of 96001 valued at ₹1.50 lakh during 2013-14. However, the cost of overall patrolling worked out to ₹11.49 lakhs for the 100 odd coast guards who spent time in implementing the ban as enforcement cost. The compensation paid to the $1,49,855$ fishermen involved in management of fishing harbours/fish landing centres are responsible for enforcement of closed fishing season without any additional cost. Patrolling during SFB is done by coast guard. The cost of patrolling worked out to ₹10.92 lakhs for the 75 odd coastal guards who were involved in implementing the ban as an enforcement cost. In this state, compensation is paid to 43,000 fishermen under centrally sponsored "Saving cum Relief Scheme." Under this scheme ₹ 900 is contributed by the beneficiary and ₹900 each by state and central governments. Thus a total ₹2,700/- is paid during the ban period. The total compensation paid was ₹11.61 crores during 2014-15.

\section{Gujarat}

In Gujarat, the enforcement is taken care by the coast guard as a part of their duty. The fishermen comply with the SFB. Hence no separate costs of enforcement are incurred. There is no specific compensation cost paid during this period. But the compensation given through the Centrally Sponsored Scheme is provided. The cost of patrolling worked out to ₹17.24 lakhs for the 100 odd coastal guards involved in implementing the ban as an enforcement cost. 


\section{Estimation of state-wise net social benefit}

The net social benefit (NSB) is worked out by deducting the transaction cost from the incremental benefit and presented in Table 8. The estimated NSB due to SFB was worked out for selected states and it was found that it was positive for all the states. The NSB in the study states ranged from ₹1,097 lakhs in Andhra Pradesh to ₹2,796 lakhs in Tamil Nadu. In the states of Tamil Nadu, Karnataka and Gujarat, the transaction cost accounted only the enforcement cost as these states do not spend any amount on information costs. The enforcement in these three states are taken care by the Marine Coastal Police and Coast Guards, whose proportion of time spent management. It was also found that, the net social benefit was positive in all these states. It ranged from ₹1,097 lakhs in Andhra Pradesh to ₹2,786 lakhs in Tamil Nadu. Hence it can be concluded that there is a substantial positive net social benefit due to enforcement of SFB in the selected states and can be recommended to continue.

The study recommends continuation of SFB owing to its positive effects. However, it is important to note that the SFB alone cannot be taken as a stand-alone measure for achieving sustainable development or conservation of resources. There are many other related management measures that need to be implemented along with SFB. A combination of several other regulatory measures

Table 8. Estimated Net Social benefit due to SFB

\begin{tabular}{llll}
\hline State & Incremental benefit (₹ lakhs) & Transaction cost (₹ lakhs) & Net social benefit (₹ lakhs) \\
\hline Andhra Pradesh & 1,266 & 168.58 & $1,097.42$ \\
Tamil Nadu & 2,809 & $12.99^{* *}$ & $2,796.01$ \\
Kerala & 2,729 & 248.14 & $2,480.86$ \\
Karnataka & 1,701 & $10.92^{* *}$ & $1,690.08$ \\
Gujarat & 2,129 & $17.24^{* *}$ & $2,111.76$ \\
\hline
\end{tabular}

At landing centre level estimate

${ }^{* *}$ In these states, enforcement of SFB is taken care by the Coast Guard, whose salary is apportioned as costs of enforcement

on enforcement is included as enforcement costs. Hence it can be concluded that there is a substantial positive NSB due to enforcement of Seasonal Fishing Ban in the selected states. However it is important to note that the compensation costs are separate from transaction costs and hence not included in calculation of NSBs. The compensation is paid by the government directly during SFB through various schemes.

Many fishery regulation measures, both input and output are tried to bring in sustainable management of marine fishery resources in the country. Among them the SFB was found to be one of the effective tools but the SFB will be more effective if used in combination with a few other regulation measures. The SFB is introduced with the major aim of conservation of resources to ensure the sustainable management of marine fishery resources and to address sea safety issues. However, almost a uniform ban period is in practice since 1998 in the maritime states with the period of ban differing from the east-coast (April 15 to May 31) and west-coast (June 15 to July 31).

The net social benefit due to the SFB was estimated using the incremental biomass and the transaction cost of implementing the SFB. The analysis on incremental benefits (biomass and its value) indicated that the SFB has a positive impact on the fish harvest after the ban and hence can be continued as a tool for sustainable marine fisheries such as minimum/maximum legal size at capture, mesh size regulation, licensing of boats, regulation of operation of motorised boats and capping the number of boats, catch quota, no-take zone, certification, Ecosystem Approach to Fisheries Management and co-management are necessary along with seasonal closure for effective replenishment of the fish stocks.

\section{Acknowledgements}

The authors gratefully acknowledge the financial support provided by the Deutsche Gesellschaftfür Internationale Zusammenarbeit (GIZ) GmbH, New Delhi, GIZ-India, Biodiversity Programme. The help and support provided by Dr. A. Gopalakrishnan, Director, ICAR-CMFRI is also acknowledged. The authors also acknowledge the help rendered by Dr. P. S. Swathilkeshmi, Principal Scientist, Dr. R. Geetha and Dr. B. Johnson, Scientists of the Socio-economic Evaluation and Technology Transfer (SEETT) Division of ICAR-CMFRI in preparation of this report

\section{References}

Barzel Yoram 1985. Transaction costs: Are they just costs? J. Instt. Theory Econ., 141(1): 4-16.

Coase Ronald 1937. The nature of the firm. Economica, 4(16): 386-405. 
CMFRI 2012. Marine fisheries census 2010. Central Marine Fisheries Research Institute, Kochi.

CMFRI 2014. Annual Report 2013-14. Central Marine Fisheries Research Institute, Kochi, 246 pp.

CMFRI 2015. Marine fish landings in India, 2014, Central Marine Fisheries Research Institute, Kochi, 6 pp.

Demsetz Harold 1968. The cost of transacting. Q. J. Econ., 82(1): 33-53.

Gordon, R. L. 1994. Regulation and economic analysis: a critique over -two centuries. Kluwer Academic Publishers, Dordrecht, The Netherlands.

Schwartzlose, R. A. J., Alheit, A., Bakun, T. R., Baumgartner, R., Cloete, R. J. M., Crawford, W. J., Fletcher, Y., Green-
Ruiz, E., Hagen, T., Kawasaki, D., Lluch-Belda, S. E., Lluch-Cota, A. D., MacCall, Y., Matsuura, M. O., NevarezMartínez, R. H., Parrish, C., Roy, R., Serra, K. V., Shust, M. N., Ward and Zuzunaga, J. Z. 1999. Worldwide largescale fluctuations of sardine and anchovy populations. South African J. Mar. Sci., 21: 289-347.

Srinath, M., Somy Kuriakose, Jayasankar, J. and Mini, K. G. 2006. Generalised fishery development model (GFDM) approach for analysis of marine fish landings in India. J. Mar. Biol. Ass. India, 48(1): 68-75.

Vivekanandan, E., Narayanakumar, R., Najmudeen, T M., Jayasankar, J. and Ramachandran, C. 2010. Marine fisheries policy brief - 2; Seasonal fishing ban. CMFRI Spl. Publn., No. 103., 44 pp 